Submitted
Accepted
Year
DOI

\title{
A GENETTIAN ANALYSIS OF THE UNFAMILIAR IN JAMES JOYCE'S "EVELINE"
}

Arzu Büşra Kumbaroğlu ${ }^{1}$

\begin{abstract}
This paper scrutinizes the conflict between the familiar and the unfamiliar in James Joyce's "Eveline" (1914), centering on the protagonist's dilemma which is deepened by a profound sense of helplessness. On the one hand, Eveline desires to stay with the familiar, namely, the home and the family in which she grew, due to the obscurity of the future and marriage. On the other hand, she cannot help but see marriage as a way to escape from her tiresome life and to be saved by the unfamiliar. This complicated the decision-making process, where she perpetually compares the past and the present time and renders the future within the limitations of her perception, reminds the stream of consciousness technique, which is frequently associated with the early $20^{\text {th }}$ century modernist writings. It seems that James Joyce, as a modernist writer, sowed the seeds of the stream of consciousness technique in "Eveline" through the protagonist's flow of consciousness before he properly used it in his later novels. This can be deduced not only from the implementation of similar narrative tools but also from the inclusion of thematic concerns such as "psychic self-dissection" and "escape" (Bradbury and McFarlane 197). Accordingly, this study analyzes Eveline's temporal-causal flow of consciousness within the framework of literary theorist Gérard Genette's narrative order, distance and perspective concepts in order to demonstrate how the text problematizes the unfamiliar, and ultimately, it aims to unearth the forces that motivate Eveline to remain within the boundaries of the familiar.
\end{abstract}

Keywords: Narrative Discourse Theory, Flow of Consciousness, Unfamiliar, Familiar, Helplessness.

\section{JAMES JOYCE'UN "EVELINE" BAŞLIKLI ESERINDEKI BILIINMEYEN KAVRAMININ GENETTECİ BİR İNCELEMESI}

\section{$\ddot{\mathbf{O} z}$}

Bu makale, James Joyce'un "Eveline" (1914) başlıklı eserindeki ana karakterin çaresizlik hissiyle derinleşen ikilemi üzerine yoğunlaşarak hikâyedeki bilinen ve bilinmeyen kavramlarının çatışmasını derinlemesine incelemektedir. Eveline, bir yandan, geleceğin ve evliliğin belirsizliğinden dolayı bilinen ile yani büyüdüğü ev ve ailesiyle kalmak ister. Diğer yandan, evliliği yorucu hayatından bir kaçış yolu ve bilinmeyen tarafından kurtarılmak olarak görür. Eveline'in devamlı olarak geçmişle bugünü kıyasladığı ve geleceği kendi algısının sınırları içerisinde yorumladığı bu karmaşık karar verme süreci, 20. yüzyıl başlarında yazılmış modernist eserlerle sık sık ilintilendirilen bilinç akışı tekniğini anımsatır. Modernist bir yazar olan James Joyce'un daha sonraki romanlarında gerçek anlamda kullanmadan önce "Eveline"de (1914) ana karakterinin bilinç akışı (flow of consciousness) sayesinde bilinç akışı tekniğinin (stream of consciousness technique) tohumlarını ektiği söylenebilir. Bu kanıya varılmasını sağlayan şey yalnızca benzer anlatı araçlarının kullanılması değil, aynı zamanda hikâyenin "kişinin zihninde kendisini incelemesi" ve "kaçış" temalarını da içinde barındırmasıdır (Bradbury and McFarlane 197). Dolayısıyla, bu çalışma Eveline'in zamansal-nedensel bilinç akışını edebiyat kuramcısı Gérard Genette'in anlatıda düzen, mesafe ve perspektif kavramları çerçevesinde inceleyerek metnin bilinmeyeni nasıl sorunsallaştırdığını göstermeyi ve en nihayetinde Eveline'i bilinenin sınırları içerisinde kalmaya yönelten kuvvetleri ortaya çıkarmayı hedefler.

Anahtar Kelimeler: Anlatı Söylemi Teorisi, Bilinç Akışı, Bilinmeyen, Bilinen, Çaresizlik.

In the letter he wrote to the publisher of Dubliners (1914), James Joyce likens his collection of short stories to "a very bold man who dares to alter in the presentment, still more to deform, whatever he has seen and heard" (Joyce et al. 134). One of them, "Eveline" (1914), presents a similar idea of deformation by introducing the problematization of the unfamiliar through the eponymous protagonist's flow of consciousness. Throughout the narrative, Eveline swings between the past and

\footnotetext{
1 Research Assistant, English Translation and Interpretation, Ankara Science University,
} arzu.kumbaroglu@hotmail.com, https://orcid.org/0000-0002-0028-1389. 
the present, comparing the familiar and the unfamiliar, each of which she associates with various objects, people, and events in her life. In part, she is appalled by the ambiguity of the unfamiliar: she fears the consequences of escape to an unknown country with her lover, Frank. Therefore, she holds on to the familiar, which is her current home and family in Dublin. Nevertheless, she also aspires to run away from the confinement, especially of her father, which leads her to see the unknown as a way of salvation. Having an important impact on her decision-making, the sense of helplessness accompanies her all along this dilemma. In this regard, this study centers on Eveline's flow of consciousness to scrutinize her decision-making process through literary theorist Gerard Genette's narrative discourse theory in order to demonstrate the extend of the narrative forces, that is, text linguistics in the emergence of the conflict between the familiar and the unfamiliar.

In "Eveline," James Joyce not only deforms the protagonist's life but he also reforms the traditional narrative techniques of his time, therefore, the implementation of flow of consciousness in this narrative is an inevitably reformative attempt for his further works. Mark Schorer, states in "Technique as Discovery" that "Under the "immense artistic preoccupations" ${ }^{1}$ of James and Conrad and Joyce, the form of novel changed, and with the technical change, analogous changes took place in substance, in point of view, in the whole conception of fiction" (74). Although Schorer here focuses on the changes made in the novel, it can be claimed that James Joyce brought "immense" reformations to narrative in general, prior to some of his great novels such as A Portrait of the Artist as a Young Man (1916) and Ulysses (1922) $)^{2}$. One of them is the use of the flow of consciousness as an antecedent to the stream of consciousness technique. The stream of consciousness technique, which appeared as an experimental narrative technique in the early $20^{\text {th }}$ century British modernist literature, has stemmed from the changes and advances in the society's institutions and conventional mindset at the end of the Victorian era. It is attributed to American psychologist William James who originally used the term in his book The Principles of Psychology (1890). James makes an analogy regarding the stream of consciousness by stating that "A 'river' or a 'stream' are the metaphors by which it is most naturally described. In talking of it hereafter, let us call it the stream of thought, of consciousness, or of subjective life" (qtd. in Bradbury and McFarlane 197). Virginia Woolf, one of the most prominent contributors to the technique of stream of consciousness in British literature, emphasizes this notion of continuity by stating that "Life is not a series of gig lamps symmetrically arranged; life is a luminous halo, a semitransparent envelope surrounding us from the beginning of consciousness to the end" (160). Likened to a stream or a luminous halo, the technique experiments with the linear narrative structure of former realist literature and incorporates the never-ending flow of the human mind and life into the modernist writings. Robert Humphrey asserts the most fundamental trait of this technique as its "subject matter" since the novels that employ the technique "have as their essential subject matter the consciousness of one or more characters" (2). In order to embody the consciousness as the subject matter, such novels exhibit distinct features of narrative discourse, that are, "incoherent thought, ungrammatical constructions, and free association of ideas, images, and words at the pre-speech level" (Luebering 171). The modernist writer employs a fragmented narrative which includes unconventional beginnings and endings, omission of punctuation marks, and lengthy sentences. Besides, the free indirect discourse in which the character's mind is conveyed by a third person narrator without the apparent intervention of the author can be regarded as a common aspect of this technique by which the narrative conveys to its reader "an ordinary mind on an ordinary day" (Woolf 160). Referring to Hofmannstal's 1893 article, Malcolm Bradbury and James McFarlane in Modernism (1976) further suggest two thematic traits of the stream of consciousness technique as "psychic self-dissection" and "escape," which are strikingly included in Eveline's flow of consciousness as well (197). Bradbury and McFarlane also state that the flow of consciousness conveys more than the external reality and claim that

There were signs that betrayed to the ... infinite change of the inner life, that reality which was not objectively given but was something subjectively perceived through consciousness.... It was a reality caught only in some flow of consciousness, a character's, the artist's. (197)

Similar to perceiving the "infinite change of inner life," Joyce's text uses Eveline's temporal-causal flow of consciousness as a tool of narrative discourse to reflect her pattern of reasoning. In the construction of the narrative, a third person narrator is utilized even though the story is largely 
conveyed through the protagonist's lenses. In addition, the text includes two epiphanic moments ${ }^{3}$ towards the end in order to accentuate its problematization. The first moment leads Eveline to have the urge of escape, whereas the second one deters her from that urge completely and finalizes the dilemma in the protagonist's mind. In this sense, not only Eveline's flow of consciousness, but also the epiphanic moments and fundamental elements of text linguistics, so to speak, foreshadow James Joyce's profound implementation of the stream of consciousness technique in his following works.

In An Introduction to Narratology (2009), the practicality of classical narratology is defined in the sense that "universality of narratological descriptive models may also be seen in narrative theory's connections to text linguistics, which also aims to explain how texts function per se" (Fludernik and Häusler-Greenfield 10). Gérard Genette's narrative discourse theory, in this regard, can be seen useful for understanding how Eveline's flow of consciousness is constructed and how the notion of flow of consciousness contributes to the formation of the narrative discourse. The categories of narrative time and narrative mood in particular, enable this study to look deeper into the temporal-causal arrangement within the text in order to find out what lies under the surface of the narrative.

In terms of the narrative time, this paper focuses on the category of order. Gérard Genette explains the relations between the time of the story and the time of the narrative as the "connections between the temporal order of succession of the events in the story and the pseudo-temporal order of their arrangement in the narrative" (35). He emphasizes that the re-arrangement of time only reflects a "pseudo-temporal order" (35). In "Eveline," James Joyce re-arranges the time of the story through the protagonist's dilemma. Genette uses the term "anachrony" for such rearrangements (35). To detect the pseudo-temporality, he proposes comparing the arranged order of events in the narrative with the order of "temporal segments" (35) in the story in order to measure "the various types of discordance between the two orderings of story and narrative" (36). He offers two general types of anachronies, analepsis and prolepsis, which will be sub-categorized in this study. He defines analepsis as "any evocation after the fact of an event that took place earlier than the point in the story where we are at any given moment" and prolepsis as "any narrative maneuver that consists of narrating of evoking in advance an event that will take place later" (40). Considering the fact that James Joyce's text reforms the conventional order of the story in line with his character's flow of consciousness, examining the anachronies would be beneficial to understand Eveline's pattern of reasoning which shuttles between the past and present time. Genette offers another category, narrative mood, in order to differentiate between "subjective and objective anachronies" (39). He refers to "two grammatical meanings of mood": firstly, the "name given to the different forms of the verb that are used to affirm more or less the thing in question" and secondly, "the different points of view from which the life or the action is looked at" (161). These definitions, when applied to Eveline's temporal-causal flow of consciousness, largely convey the character's perception through both the narrator's words and the protagonist's own lenses. According to Genette, the narrative mood contains "two chief modalities" which are "distance" and "perspective" that help to regulate the information given in the narrative (162). Distance which is created by different forms of verb acts as a block before the text in variable degrees, whereas perspective refers to the "focal character" (188) which is the one who sees (162). However, Eveline's pattern of reasoning presents a nonlinear order of time and causality to the reader. Seymour Chatman mentions such use of nonlinearity between sequence and causality in the modern texts by asserting that "Certainly modern authors claim to reject or modify the notion of strict causality" (47). In this sense, this paper will follow Eveline's pseudo-temporal and causal flow of consciousness in its nonlinear order to examine how James Joyce, as a modern and modernist author, rearranges the order of the events in the narrative and how this rearrangement contributes to Eveline's subjective causality. In this sense, Genette's order will be more convenient for examining Eveline's pattern of comparison between the past and the present, whereas distance and perspective will provide an insight into her deductions about the future. In this way, this study aims to analyze how Joyce's text problematizes the concept of the unfamiliar in opposition to the familiar and how Eveline's helplessness ultimately seizes her entire flow of consciousness, leading her to stay within the boundaries of the familiar.

"Eveline" begins with the protagonist sitting by the window and passively watching the passer-bys. Despite being depicted by a third person narrator, the subjective statements such as "odour of dusty cretonne" and feeling "tired" (Joyce 41) hints the perception of Eveline, which makes her the 
focal character. In this sense, it can be said that the voice might not always equal to the point of view presented in the narrative. Genette clearly emphasizes the vitality of distinguishing between who speaks and who sees in order to avoid a "regrettable confusion" (186). Beginning with such distinction, the narrative manages to take a step into the character's consciousness and reveals that, despite being narrated in the third person, it can still convey the point of view of the character.

Even though Eveline poses a passive look on the surface, her mind is engaged with a complicated decision-making process. The text represents this with the implementation of anachronies. Watching the field by her house, Eveline thinks about the past and how "children of the avenue used to play together in that field" (Joyce 41). As the narrative has just begun, this anachrony can be regarded as an external analepsis since it does not "risk interfering with the first narrative, for their only function is to fill out the first narrative by enlightening the reader on one or another "antecedent"" (Genette 50). The first narrative here is Eveline in the external world while the other one would be her flow of consciousness. Despite being a part of the flow, this memory plays an introductory role for Eveline's past. She continues to interpret those days as they were "happy then" since she remembers that "her father was not so bad then; and besides, her mother was alive" (Joyce 41). This reminiscence can be regarded as a repeating prolepsis (advance notice) which hints the upcoming presentation of the father as a harsh man. As Eveline keeps pondering, it becomes apparent that "that was a long time ago; she and her brothers were all grown up; her mother was dead" (41). The earlier retrospection takes the form of a completing analepsis (return) when it is stated to have ended "a long time ago." Genette describes returns as "retrospective sections that fill in, after the event, an earlier gap in the narrative" (50). The return enables the reader to connect the pieces scattered within Eveline's flow of consciousness. It also highlights the protagonist's inclination towards nostalgia against the confinement of her life. Eveline desires to take a shelter in her past in order to escape from her present situation. Therefore, with the thought of good old days, Eveline's external passivity is violated by internal yearnings for nostalgia.

Indeed, the majority of the narrative problematizes the concept of the unfamiliar by conflicting it with the nostalgia for the familiar. For this purpose, he uses both perspective and distance in Gérard Genette's narrative mood. Describing the modern novelists such as James Joyce as "post-Jamesian partisans," Genette quotes Norman Friedman ${ }^{4}$ to describe the "best narrative form" as "the story told as if by a character in the story, but told in the third person" (168). Although at first glance his description connotes the technique of stream of consciousness, his following explanation suits better to the use of the "flow of consciousness" in "Eveline" as an antecedent to that technique. As Genette conveys, the implied character is a narrator "who is not one of the characters but who adopts the point of view of one" (168). He continues to quote from Friedman, stating that "the reader perceives the action as it filters through the consciousness of one of the characters involved," and in this way it manages to avoid "that removal to a distance necessitated by retrospective first-person narrator" (168). This description largely relates to the use of the flow of consciousness in "Eveline" since he also portrays the conflict between the familiar and the unfamiliar in Eveline's mind using similar tools of narrative discourse. To exemplify, the sentence in free indirect discourse "everything changes," which obviously belongs to Eveline's flow of consciousness, is completed by the third person narrator as follows: "Now she was going to go away like the others, to leave her home" (Joyce 41). At this point, both the character and the third person narrator make it crystal-clear that she is determined to escape. In a way, it can be deduced that her initial escape into the abstract notion of the past influences the progression of her decision-making process. Just like a cycle, the idea of escape as an example of repeating prolepsis or advance notice ${ }^{5}$ reminds the nostalgia that surrounds her. Her home, for instance, is described to have "familiar objects from which she had never dreamed of being divided" (41). The sense of helplessness slowly creeps into her, reminding her possible dangers in her prospective life within the unfamiliar. Therefore, diving into Eveline's causal flow of consciousness, the text is able to create a conflict between the familiar and the unfamiliar. Eveline looks around to see "the familiar objects which she had dusted once a week for so many years" (41). Here, the image of dust reflects her sense of confinement. The narrator maintains, "She had consented to go away, to leave her home" (41). Indeed, the word consent implies the incapability and dependency of Eveline. Ultimately, it seems that she counts on someone or something else that she knows than her own self while making her decision. 
The repeated use of the "free indirect style" (Genette 172) as a part of distance in the statements such as "everything changes" and "was that wise" also reflects Eveline's helplessness in the middle of her dilemma (Joyce 41). Gérard Genette regards the "free indirect style" as a type of narration "where economizing on subordination allows a greater extension of the speech, and thus beginning of emancipation despite the temporal transpositions" (172). "Eveline" does not create such strong "emancipation" for the character, yet, "free indirect style" in the narration of the flow of consciousness manages to associate the conflict between the familiar and the unfamiliar with Eveline's dilemma without much intervention by the author. Genette's free indirect discourse is a form in which "the narrator takes on the speech of the character, or if one prefers, the character speaks through the voice of the narrator, and the two instances are then merged" (174). Similarly, this article tries to clarify the sense of helplessness reflected in the character's mind by associating it with the narrator's account of Eveline's visible helplessness.

Following the free indirect discourse, internal focalization is another element of Gérard Genette's narrative discourse theory that Joyce's narrator exemplifies as follows: "She tried to weigh each side of the question. In her home anyway she had shelter and food; she had those whom she had known all her life around her" (Joyce 41-42). Irrespective of the third person narrator, the text reflects Eveline's hesitation against the confinement of the familiar with internal focalization. In this regard, Genette states that a strict internal focalization is almost impossible, yet, it can be considered "in a necessarily less strict sense" (193). Thus, he refers to Roland Barthes' "personal mode of narrative" 6 (193). He explains that, according to Barthes, if one can convert the "grammatical pronouns" of the "narrative section ... into the first person, ... it belongs to internal focalization" (193). When the pronoun she in the mentioned sentence is replaced with the pronoun I as I tried to weigh each side of the question, it can be seen that Eveline ponders on her dilemma in a "less strict" internal focalization (193). Derek Attridge, in The Cambridge Companion to James Joyce (2004) expresses that "Eveline" could not be wholly converted into the first person, yet, closely analyzing the "individual words and turns of phrase," it would be possible to proceed "through continually shifting perspectives" (6).

As an embodiment of such shifting perspectives, it can be said that although Eveline is intimidated by the ambiguity of marriage, she believes that marriage would grant her respect and protection. The narrative indicates Eveline's need of protection by using a repeating analepsis (recall) in which she can compare and contrast the past and the present. Gérard Genette explains that recalls, "sometimes explicitly, retraces its own path" (54). Even though Eveline initially remembers her father as being "not so bad" (Joyce 41) in the past, she gradually deduces that

When they were growing up he had never gone for her, ... but latterly he had begun to threaten her and say what he would do to her only for her dead mother's sake.

And now she had nobody to protect her. (42)

This comparison intensifies her need of protection. Strikingly, the same memory also evokes her sympathy when she ponders on the ambiguity of future in "an unknown distant country" (42). The narrator states, "It was hard work - a hard life - but now that she was about to leave it she did not find it a wholly undesirable life" (42). Genette attributes such changes to recalls which "suggest a comparison between the present and the past, a comparison comforting for once, since the moment of reminiscence is always euphoric, even if it revives a past that in itself was painful" (55). Through recalls, as with the internal focalization, the shifting perspectives in Eveline's mind become concrete elements of text linguistics that could practically help to analyze the protagonist's pseudo-temporal flow of consciousness.

However, the textual elements are not the only means by which Eveline's subjective point of view is presented. Indeed, her subjectivity is apparent in the representation of individuals or places within the narrative. Her subjective perception towards individuals can be seen clearly when she depicts Frank as an ideal lover. She imagines that

She was about to explore another life with Frank. Frank was very kind, manly, openhearted. She was to go away with him by the boat to be his wife and to live with him in Buenos Ayres where he had a home waiting for her. (Joyce 43) 
This description portrays a perfect lover for the reader even though the subsequent completing prolepses reflect her inner doubts about Frank's personality and the future in the unknown land. In Critical Companion to James Joyce (2006), a similar interpretation of Eveline's subjectivity is conveyed as follows:

Because a good portion of the reader's information comes from Eveline's point of view, nothing from her sense of the world has the assurance of an objective account. At the same time that she tells us about the trials of her life, the narrative pulls back to show the flaws that inhibit her observation. (Fargnoli and Gillespie 53)

Even though later on it becomes obvious that she has not known Frank for long, here Eveline fancifully presents a perfect image of him. Likewise, spatial descriptions are also effective in demonstrating Eveline's point of view regarding the conflict between the familiar and the unfamiliar. Amina Megheirbi suggests that contradictions between certain spatial elements in a text can "signify different meaning because they are culturally and contextually shaped. Actually, narrative discourse can either validate that meaning or reject it completely" (23). Similarly, distinguishing between home and house, Eveline associates the idea of home with a safe place where she can live with her current family or build a new one through marriage. Even though the latter begins with the unfamiliar, it can be said that, for Eveline, any environment that provides security might feel like the familiar. The following completing analepsis, which provides a clearer insight into Eveline's flow of consciousness, repeats the same spatial dichotomy. She remembers the first time she saw Frank when "he was lodging in a house on the main road where she used to visit" (Joyce 43). Even though she knows the place, it does not feel like home. In this sense, it can be said that most of Eveline's accounts stem from her subjective perception.

As the narrative continues, the previous completing analepsis about Frank turns into a repeating analepsis and Eveline's imaginative point of view is once again introduced as follows: "It seemed a few weeks ago. He was standing at the gate, his peaked cap punched back on his head and his hair fumbled forward over a face of bronze. Then they had come to know each other" (Joyce 43). As the narrator and the character merge into one, what is conveyed is only Eveline's fascination of the unfamiliar. Indeed, this fascination initially suppresses Eveline's sense of helplessness as she eagerly remembers that "He had tales of distant countries" (43). Eveline attributes a mystical existence to Frank. However, the following use of the "transposed speech in indirect style" (Genette 171) reflects a degree of unreliability in the narrative discourse when Eveline remembers, "He had fallen on his feet in Buenos Ayres, he said, and had come over to the old country just for holiday" (Joyce 43). Genette explains that "this form [transposed speech] never gives the reader any guarantee ... of literal fidelity to the words 'really' uttered: the narrator's presence is still too perceptible in the very syntax of the sentence" (171). This air of unreliability actually reflects Eveline's doubts about her future in Buenos Aires. The fact that her father disapproves the "sailor chap" (Joyce 43) reinforces the unreliability conveyed through the narrative tool. Sense of helplessness gradually creeps in her flow of consciousness and makes her question the unfamiliar.

The more Eveline approaches the moment of escape, the deeper her sense of helplessness becomes. The white of two letters she has written to Harry and her father merge into one as she dives into memories again. She thinks to herself that "Her father was becoming old lately, she noticed; he would miss her. Sometimes he could be very nice" (Joyce 43). Once again, the use of the transposed speech in indirect style with the declarative verb "she noticed" hints the existence of the narrator even though the narrative belongs to Eveline's flow of consciousness. The sense of helplessness urges her to cling to the familiar. The completing prolepsis about her anticipation of longing for her father is reinforced when she remembers a recent good time with him, thinking, "Not long before, when she had been laid up for a day, he had read her out a ghost story and made a toast for her at the fire" (43). This repeating analepsis is followed by a completing analepsis as she recalls, "Another day, when their mother was alive, they had all gone for a picnic to the Hill of Howth. She remembered her father putting on her mother's bonnet to make the children laugh" (43). Eveline's pseudo-temporal and causal flow of consciousness that she rearranges the order of the memories retraces her past from the near past to the far past. Such nostalgic yearnings highlight the significance of the familiar as opposed to the unfamiliar. Even though Eveline sees the unfamiliar as a way to escape from her tiresome life, 
the text's problematization of the unfamiliar shows itself in such moments of nostalgia which triggers Eveline's sense of vulnerability against the unknown.

Likewise, the familiar begins to suppress the unfamiliar as she connects the familiar tune of "a street organ playing" with "her promise to keep the home together as long as she could" (Joyce 44). Nevertheless, this song also reminds her of her mother's illness when she remembers that "as she mused the pitiful vision of her mother's life laid its spell on the very quick of her being - that life commonplace sacrifices closing in final craziness" (44). Eveline, for a moment, associates the idea of marriage with the unfamiliar, which would bring misery in the end. This advance notice hints that Eveline will be appalled by the ambiguity of the future at the real moment of escape. Nevertheless, helplessness still leads her to confuse the protection of the familiar with the expected protection of the unfamiliar. Garry Leonard explains this delusion, asking,

But to what, and to whom, is she returning? Nothing more or less than: an increasingly violent alcoholic father who has no one but her to beat ... and a thankless exhausting job where even her salary is not her own. (Attridge 94)

Apparently, Eveline holds her father responsible for the tiresome life she leads, which brings forth an epiphanic moment as the narrator conveys, "She stood up in a sudden impulse of terror. Escape! She must escape! Frank would save her.... Frank would take her in his arms, fold her in his arms. He would save her" (Joyce 44). Once again, the existence of the free indirect discourse mirrors her subjective point of view. It becomes apparent that she desperately needs someone to rescue her. The amalgamation of pseudo-temporal and causal flow of consciousness with the free indirect discourse reflects Eveline's deviation from the reality that, unlike her, the narrator can comprehend. Eveline's fearful perspective is also apparent at the station scene when Frank speaks to her but she is not able to hear. Amid the image of the boat "blowing a long mournful whistle into the mist," Eveline sinks into the thoughts on her prospective life in the unfamiliar (44). The following sentence in free indirect discourse hints that Eveline actually desires to stay with the familiar though she feels responsible towards Frank. She thinks, "Could she still draw back after all he had done for her?" (44). As it has been exemplified, Eveline can remember her father's occasional affection. Even though she knows that life is hard with her father, she is also aware that "he would miss her" (43). This contradiction between love and responsibility accentuates her panic in escaping to the unfamiliar.

The second epiphanic moment, triggered by the problematization of the unfamiliar, verifies her panic as the narrator conveys, "all the seas of the world tumbled about her heart. He was drawing her into them: he would drown her. She gripped with both hands at the iron railing" (Joyce 44). The repeating analepsis (recall) of Frank's saving arms turn into a force that would "drown" her. According to Genette, this is "the most persistent function" of recalls, having the power to modify "the meaning of past occurrences after the event ... by refuting a first interpretation and replacing it with a new one" (56). Here, Eveline reinterprets her life within its familiar environment. She notices that the certainty of the familiar, even though it is not always pleasant, precedes the obscurity of the unfamiliar.

When Eveline is about to board on the boat with Frank, the fear and helplessness take over the control and convince her to stay with the familiar. In her mind she screams, "No! No! No! It was impossible. Her hands clutched the iron in frenzy. Amid the seas she sent a cry of anguish!" (Joyce 45). Even though she is curious about the unknown land, she finally comprehends her dependency on her family in Dublin. T. Patrick Murphy illustrates the protagonist's helplessness, stating that "Eveline's extended reverie serves to uncover a profound danger. If Eveline chooses to act, she will cause catastrophe. It is only by means of act of reinterpretation - by rereading the meaning of her past experience - that she can avoid disaster" (115). As the narrative ends, the eye that sees becomes the narrator. The narrator observes Eveline from the outside and depicts her "helpless" expression, stating that "She set her white face to him, passive, like a helpless animal. Her eyes gave him no sign of love or farewell or recognition" (Joyce 45). At this point, the dilemma between the familiar and the unfamiliar turns in favor of the familiar. Fear and dependency outrival the temptation of the unknown.

Consequently, it is essential to note that what enables the character to distinguish the familiar from the unfamiliar is the implementation of the flow of consciousness along with other significant 
narrative tools. Throughout the narrative, Eveline's consciousness goes back and forth between the past and the present, trying to come up with anticipations about the future. Ultimately, Eveline comprehends the roots that enclose her within the boundaries of the familiar such as her home, her family or the promise she has given to her deceased mother. On the other hand, the peak of her helplessness stems from the obscurity of the future and marriage in an unknown land with an unknown sailor. In conclusion, the analysis of Joyce's text with Genette's narrative discourse theory reveals that the problematization of the unfamiliar throughout the narrative gives the protagonist a chance to compare and contrast the binaries such as the past and the present, home and house, and in general, the familiar and the unfamiliar. Moreover, the final epiphanic moment reveals the dilemma in the consciousness of Eveline more clearly, leaving her with an awareness of where she belongs. It can be said that Joyce ultimately manages "to deform, whatever he has seen and heard" without an apparent intervention into the narrative (Joyce et al. 134). This becomes possible with the use of Eveline's flow of consciousness as a part of the narrative discourse. Not only that, but also the linguistic attempts in "Eveline" can be interpreted as a preview of James Joyce's authentic use of the stream of consciousness technique in his later novels. In this sense, by scrutinizing Eveline's pseudo-temporal and causal flow of consciousness with Genettian narrative discourse theory, this article both glances at James Joyce's evolving technique in terms of narrative discourse and demonstrates that the conflict between the familiar and the unfamiliar is deeper than the surface level of Eveline's dilemma. As Genette openly states, "Narrative always says less than it knows, but it often makes known more than it says" (198). Analyzing the text's problematization of the unfamiliar within the framework of Genette's theory, this study reveals the forces that persuades Eveline to remain within the boundaries of the familiar.

\section{NOTES}

1. In his book H. G. Wells: Traversing Time, W. Warren Wagar explains that in the introduction part of his biography written by Geoffrey West, H. G. Wells refers to Henry James, Joseph Conrad, and Mr. Ford Madox Hueffer as follows: "I escaped from under their immense artistic preoccupations by calling myself a journalist" (qtd. in Wagar 8). In his own article, Mark Schorer seems to have added James Joyce to the list as one of the great names that had a part in changing the form of the novel.

2. Some scholars trace James Joyce's use of the stream of consciousness technique in Ulysess (1922) back to Édouard Dujardin's novel Les Lauriers sont coupés (1887). Steven Huebner points out that "throughout his career after that point [Ulysess], Joyce openly acknowledged his debt to Dujardin for having been the first writer to use stream of consciousness in Les Lauriers sont coupés" (Huebner 56). Lawrence E. Bowling reinforces this statement by suggesting that James Joyce has "perfected and popularized" (Bowling 340) monologue intérieur by Édouard Dujardin, which is, as Steven Huebner explains, the French writer's naming of the stream of consciousness technique (Huebner 86).

3. In his posthumous book Stephen Hero, first published in 1944, James Joyce names those epiphanic moments as "epiphany" which is "a sudden spiritual manifestation, whether in the vulgarity of speech or of gesture or of a memorable phase of the mind itself" (Joyce and Spencer 215).

4. Friedman, Norman. "Point of View in Fiction: The Development of a Critical Concept." The Theory of the Novel. Ed. Ph. Stevick New York: Free, 1967. Web. 19 April 2020.

5. Genette describes it as "an event that will be told in full in its place" (Genette 73).

6. Barthes, Roland, and Lionel Duisit. "An Introduction to the Structural Analysis of Narrative." New literary history 6.2 (1975): 237-272. Web. 19 April 2020.

7. Genette differentiates between transposed speech in indirect style and free indirect speech, emphasizing the fact that the free indirect discourse has the power of emancipation as well as it lacks declarative verbs that the former one possesses (Genette 172). 


\section{WORKS CITED}

Attridge, Derek, ed. The Cambridge Companion to James Joyce. Cambridge University Press, 2004. Web. 19 April 2020.

Bowling, Lawrence Edward. "What is the Stream of Consciousness Technique?" Publications of the Modern Language Association of America. (1950): 333-345. Web. 21 November 2020.

Bradbury, Malcolm and James McFarlane, ed. Modernism 1890-1930. Penguin Books, 1976. Web. 19 April 2020.

Chatman, Seymour Benjamin. Story and Discourse: Narrative Structure in Fiction and Film. Cornell University Press, 1980. Web. 19 April 2020.

Fargnoli, A. Nicholas, and Michael Patrick Gillespie. Critical Companion to James Joyce: A Literary Reference to His Life and Work. Infobase Publishing, 2014. Web. 19 April 2020.

Fludernik, Monika, and Patricia Häusler-Greenfield. An Introduction to Narratology. Taylor \& Francis e-Library, 2009. Web. 19 April 2020.

Genette, Gérard. Narrative Discourse: An Essay in Method. Ithaca: Cornell University Press, 1980. Web. 19 April 2020.

Huebner, Steven. "Édouard Dujardin, Wagner, and the Origins of Stream of Consciousness Writing." 19th-Century Music 37.1 (2013): 56-88. Web. 21 November 2020.

Humphrey, Robert. Stream of Consciousness in the Modern Novel. University of California Press, 1958. Web. 21 November 2020.

Joyce, James, and Theodore Spencer. Stephen Hero: Part of the First Draft of 'A Portrait of the Artist As a Young Man'. London: Jonathan Cape, 1960. Web. 19 April 2020.

Joyce, James, et al. Letters of James Joyce. London: Faber and Faber, 1957. Web. 19 April 2020.

Joyce, James. Dubliners. Ankara: Engin Yayınevi, 2015. Print.

Luebering, J. E., ed. English Literature from the 19th Century through Today. Britannica Educational Publishing, 2010. Web. 21 November 2020.

Megheirbi, Amina. Structure of Modernist Narrative Discourse in a Changing World in "The Sound and the Fury" and "The Grapes of Wrath" PhD Dissertation. İstanbul Aydın University, İstanbul, 2018. Dissertations and Thesis: Full-Text. Ulusal Tez Merkezi. Web. 19 April 2020.

Murphy, Terence Patrick. "Interpreting marked order narration: The case of James Joyce's 'Eveline'.” Journal of Literary Semantics 34.2 (2005): 107-124. Web. 19 April 2020.

Schorer, Mark. "Technique as Discovery.” The Hudson Review 1.1 (1948): 67-87. Web. 19 April 2020.

Wagar, W. Warren. H.G. Wells: Traversing Time. Wesleyan University Press, 2004. Web. 19 April 2020.

Woolf, Virginia. "Modern Fiction.” The Essays of Virginia Woolf. Vol. 4: 1925 to 1928. Virginia Woolf and Andrew McNeillie. London: Hogarth Press, 1984. 157-165. Web. 21 November 2020 . 